\title{
Sejarah pendidikan Islam; kontribusi Islam dalam mengembangkan sains dan teknologi
}

\author{
Edi Susanto a,1, ${ }^{\text {, }}$, Diyah Ayu M b,2 \\ *a Sekolah Tinggi Agama Islam Brebes, Jawa Tengah, Indonesia, 52211 \\ b STAINU Temanggung, Jawa Tengah, Indonesia, 56229 \\ 1 edisusanto@gmail.com; ${ }^{2}$ diahayum@gmail.com \\ *Correspondent Author
}

Received:

Revised:

Accepted:

KAT A KUNCI

Sejarah

Kontribusi

Sains

Teknologis

\section{KEYWORDS}

History

History

Science

Technology
ABSTRAK

Latar belakang masalah dalam penelitian ini berawal dari Banyak pihak di luar Islam telah menafikan sains dan teknologi dalam Islam. Anggapan mereka Islam tidak mengenal sains dan teknologi yang sebagian besar mereka temukan. Realitas sejarah membuktikan bahwa dari sisi kualitas, kemajuan sains daan teknologi umat Islam pernah melampaui kualitas sains dan teknologi pada saat ini, bisa dilihat dengan kualitas ilmuwan dan karya-karya yang dihasilkan. Adapun dari sisi kuantitas, kejayaan sains dan teknologi umat Islam sangat lama, sehingga kejayaan Barat dalam penguasaan sains dan teknologi belum sebanding dengan lamanya kejayaan sains dan teknologi Islam. Saat ini, Barat sedang mengalami kejayaan di bidang sains dan teknologi, akan tetapi krisis kepercayaan juga melanda merekaa karena sekulerisme dan aatheisme yang mereka anut. Adapun Islam, saat ini sedang berupaya menguasai sains dan teknologi Barat, belum sampai pada persaingan dalam produksi sains dan teknologi. Kebangkitan sains dan teknologi dapat ditempuh jika ada upaya integrasi secaya nyata ilmu umum dengan agama.

history of Islamic education; the contribution of Islam in developing science and technology

The background to the problem in this research stems from many parties outside of Islam who deny science and technology in Islam. Their assumption is that Islam does not know the science and technology that they have mostly discovered. Historical reality proves that in terms of quality, the advancement of science and technology of Muslims has ever surpassed the quality of science and technology at this time, it can be seen from the quality of scientists and the works produced. In terms of quantity, the glory of science and technology of Muslims is very long, so that the glory of the West in mastering science and technology has not been comparable to the length of the glory of Islamic science and technology. Currently, the West is experiencing victories in the fields of science and technology, but a crisis of confidence has also hit them because of their secularism and aatheism. As for Islam, currently it is trying to master Western science and technology, not until the competition in the production of science and technology. The revival of science and technology can be pursued if there is an effort to realistically integrate general science with religion. 


\section{Pendahuluan}

Banyak pihak di luar Islam telah menafikan sains dan teknologi dalam Islam(AR, 2016). Anggapan mereka Islam tidak mengenal sains dan teknologi yang sebagian besar mereka temukan. Paham sekulerisme(Nashir, 2002) yang juga berujung pada atheisme(Baharudin, 2016), semakin manambah klaim kebenaran tentang jauhnya Islam dari sains dan teknologi. Padahal secara historis, Islam merupakan titik awal dari perkembangan sains yang saat ini banyak menghasilkan penemuan-penemuan berupa teknologi baru. Kontruksi dasar sains yang dibangun oleh Islam pada amasa dahulu, dianggap tidak ada hubungn dengan perkembangan sains dan teknologi yang terjadi saat ini. Permasalahan penguasaan sains dan teknologi dalam Islam yang minim pada dasarnya merupakan permasalahan epistimologis(Nurdin et al., 2019), yang berputar pada proses perumusan ilmu dalam Islam. Selain itu, faktor keberuntungan menjadi menyebab awal mundurnya sains daan teknologi dalam Islam. Penyerbuan dan penghancuran kota Bagdad sebagai pusat ilmu pengetahuan Islam oleh Hulagu Khan, menjadi awal kehancuran ilmu pengetahuan dalam Islam. Setelah itu, proses perumusan konsep ilmu Islam yang dirumuskan oleh para pemikir Islam juga menjadi kata kunci penting bagi perkembangan sains dan teknologi dalam Islam saat ini. Aspek Teologi(Mukhlis, 2015) yang lebih diutamakan dari pada ilmu sosial menjadikan Islam saat ini jauh dari penguasaan sains dan teknologi, apalagi berkaitan dengan penemuanpenemuana baru bidang teknologi.

Terdapat banyak pernyataan al-Qur'an dan Hadits mengenai kewajiban umat Islam untuk menyelidiki dan mempelajari alam semesta. Penyelidikan merupakan awal mula munculnya sains dan teknologi sebagai sebuah penemuan baru. Objektif pemerhatian penyelidikan mengenai alam semesta harus memenuhi dua objektif, yaitu mengenal secara terperinci hukum alam dan mengambil faedah darinya dari sudut gunaan atas sifat manusia adalah khalifah Allah(Mardliyah et al., 2018). Dua hal ini harus diperhatikan secara seimbang dalam mengembangkan sains dan teknologi Islam.

Pada dasarnya ada dua pondasi utama atau substansial yang dirumuskan oleh sains Islam pada masa itu, yaitu tauhid dan hukum kausalitas yang bersumber pada alam semesta dan seisinya. Barat yang saat ini mengklaim sains dan teknologi yang maju saat ini sebagai kontribusi dari filsafat yunani, mengubur dalam-dalam ilmu tauhid yang telah dikembangkan dalam Islam. Mereka hanya mengembangkan hukum kausalitas untuk meneliti tentang alama semesta dan seisinya. Stagnansi agama dan semakin pesatnya sains dan teknologi yang berdasar pada hukum kausalitas(Qoqom, 2019) menghasilkan sifat matrealistis, hedonis, dan sekuleristis, yang pada ahirnya memunculkan atheis di Barat. Hal ini menyebabkan perkembangan sains dan teknologi Barat saat ini jauh dari agama. Untuk itu, sebenarnya Barat saat ini sedang mengalami krisis kepercayaan terhadap Tuhan, sehingga terbukti dengan semakin bertambah pesatnya para saintist Barat yang memeluk agama Islam. Sebagai manusia yang sudah memilih Islam sebagai agama yang didyakini, seyogyanya juga harus mengimbangi kemampuan diri dengan penguasaan dan bahkan pengembangan sains dan teknologi.

Untuk itu, penting kiranya melakukan dekonstruksi dan redeskripsi(Siregar, 2019) lagi terhadap sains dan teknologi dalam Islam guna mengungkap kontribusi Islam dalam perkembangan sains dan teknologi. Hal ini penting dilakukan guna mengungkap kembali konsepsi sains yang sudah ada pada masa itu. Menurut Ziauddin Sardar, kelangsungan sains 
dan teknologi Islam selalu didasarkan atas asas nilai, konsep, dan nilai-nilai yang ada dalam Islam. Tauhid, khilafah, ibadah, halal, haram, adil dan zalim, istislah dan dhiya adalah asas penting yang ada dalam sains dan teknologi. Perpaduan antara konsepsi sains dan teknologi dalam Islam dengan asas Islam tersebut, akan melahirkan sains dan teknologi yang tidak hanya aplikatif tetapi juga normatif.

Guna mengungkap kontribusi nyata Islam dalam perkembangan sains dan teknologi, secara historis perlu diketahui mengenai konsepsi Islam tentang sains dan teknologi, kondisi sains dan teknologi pada masa kejayaan Islam, Perkembangan sains dan teknologi Islam, serta faktor penghambat kemajuan sains dan teknologi Islam(Mutia, 2018).

Ahirnya, mudah-mudahan karya tulis ini dapat member manfaat bagi semua pembaca. Meskipun demikian penulis mengharap saran dan kritik demi kesempurnaan kaarya tulis ini.

\section{Metode}

Penelitian ini termasuk jenis penelitian literer(Sari \& Asmendri, 2018) yang menggunakan pendekatan sejarah(Syarifuddin, 2018) dalam mengkaji sumber-sumber sejarah pendidikan Islam. Penelitian kualitatif(Prasanti, 2018) ini menggunakan metode pengumpulan data literer dengan sumber data berupa buku dan publikasi ilmiah lain yang relevan. Penelusuran sumber data dimulai dari pemetaan fokus penelitian.

\section{Hasil dan Pembahasan}

\section{Konsepsi Islam tentang Sains dan Teknologi}

Salah satu ciri yang membedakan Islam dengan agama lainnya adalah penekanannya terhadap masalah ilmu pengetahuan (sains). Kedua sumber hukum utama Islam, yaitu alQur'an dan as-Sunah, mengajak kaum Muslim untuk mencari dan mendapatkan ilmu dan kearifan(Basyir, 2019) serta menempatkan oraang-orang yang berpengetahuan pada derajat yang tinggi. Dalam kumpulan wahyu Allah SWT, yaitu al-Qur'an dan as-Sunah, kata al-'ilm ternyata memang banya disebut, yaitu sebanyak 105 kali, lebih banyak sedikit dari penyebutan kata al-din yang sebanyak 103 kali. Tapi dengan kata jadiannya, kata 'ilm tersebut tidak kurang dari 744 kali. Hal itu kiranya tidak berlebihan, jika diingkat bahwa wahyu pertama yang turun kepada Rasulullah adalah perintah untuk membaca yang artinya:

Bacalah dengan nama Tuhanmu yang mencipta (Q.S. al-'Alaq:1)

Setelah diingatkan bahwa manusia itu diciptakan dari segumpal darah, memberikan kesadaran ontologism bahwa Tuhan itu selain Maha Pencipta, juga Maha Pemurah, serta memberikan kesadaran etis bahwa Tuhan memberikan ilmu kepada manusia lewat perantara pena. Maka sebenarnya yang dibawa sejak semula oleh alQur'an adalah dua semangat kembar, yaitu tauhid dan keilmuan(Hadi, 2016).

Ada banyak ayat yang menganjurkan manusia untuk memperhatikan dan menyelidiki alam semesta dan segala fenomena yang terjadi didalamnya, antara lain: Surah al A'raf (7): 185 Artinya:

"Patutkah mereka (membutakan mata) tidak mahu memerhatikan alam langit dan bumi dan seagla yang diciptakan Allah dan (memikirkan) bahawa harus telah dekat ajal kebinasaan mereka".

Surah Qaaf (50): 6-8 Artinya:

"Kalaulah mereka menyangka Kami tidak berkuasa mengembalikan mereka hidup semula, maka tidakkah mereka memandang ke langit, bagaimana kami membinanya serta kami hiaskannya dengan bintang-bintang dengan keadaan tidak ada padanya retak renggang...”.

Surah Ali Imran (3): 190 Artinya:

"Sesungguhnya pada kejadian langit dan bumi dan pada pertukaran malam dan siang ada 
tanda-tanda kekuasaan, kebijaksanaan dan kekuasaan rahmat Allah bagi orangorang yang berakal".

Surah Fussilat (41): 53 Artinya:

"Kami akan perlihatkan kepada mereka tanda-tanda kekuasaan Kami di mana-mana tempat dalam alam yang terbentang luas ini dan pada diri mereka sendiri, sehingga ternyata jelas kepada mereka bahawa al Quran adalah benar".

Seruan dan arahan pernyataan Allah ini telah menjadi titik tolak kepada ilmuan Islam mengkaji mengenai alam dan fenomenanya. Selanjutnya, pengkajian tersebut melahirkan saintist dan teknologi Islam dalam berbagai disiplin ilmu sains dan teknologi. Di dalam Hadist Nabi juga ada pernyataan yang memuji orang-orang terdidik. Sejumlah Hadist mengenai hal ini dinisbahkan kepada Nabi yang mengandung anjuran, bahkan perintah seperti yang kita kenal bahwa mencari itu wajib bagi setiap Muslim, carilah ilmu walaupun sampai ke negeri Cina, carilah ilmu sejak dari buaian sampai ke liang lahat, para ulama itu pewaris para Nabi.

Pada umumnya, pembahasan tentang epistemologi (teori pengetahuan) dimulai dengan penjelasan mengenai definisi yang biasanya dibedakan dengan pengetahuan (knowledge). Tidak pernah jelas, misalnya apakah sains itu sam dengan ilmu. Hal ini menyebabkan sains sama dengan ilmu. Istilah ilmu pengetahuan juga terkadang dipaki untuk merujuk sains yang dibedakan dengan pengetahuan. Istilah ilmu dalam epistemologi Islam mempunyai kemiripan dengan istilah sains dalam epistemologi Barat. Sebagaimana sains dalam epistemologi Barat dibedakan dengan knowledge, ilmu dalam epistemologi Islam dibedakan dengan opini (ra'y). sementara sians dipandang sebagai any organized knowledge yaitu pengetahuan yang terorganisir(Firman, 2018), ilmu didefinisikan sebagai ma'rifat al-syai' 'ala ma huwa bihi (pengetahuan tentang sesuatu sebagaimana apa adanya). Dengan demikian, ilmu bukan sembarang pengetahauan atau sekedar opini, melainkan pengetahuan yang telah teruji kebenarannya. Pengertian ilmu sebenarnya tidak jauh berbeda dengan sains, hanya saja sains dibatasi pada bidang-bidang fisik atau indrawi. Adapun ilmu melampaauinya pada bidang-bidang non-fisik, seperti metafisika. Penyetaraan istilah ini dapat diperkuat oleh pernyataan karier, pengarang buku Scientist of the Mind, bahwa pada masa-masa awal abad ke-19, sains dipahami sebagai any organized knowledge atau pengetahuan yang terorganisir, termasuk Teologi.

Permasalahan ilmu-ilmu yang dimasukan dalam Islam merupakan pokok penting yang mendasar sejak hari-hari pertama Islam. Sebagian besar ulama hanya memasukan cabangcabang ilmu yang secara langsung berhubungan dengan agama. Sedangkan ilmu-ilmu yang lain diserahkan kepada masyarakat untuk menentukan sendiri ilmu yang esensial dan urgen dipelajari.

\section{Kondisi Sains dan Teknologi Pada Masa Kejayaan Islam}

Abu Hasyim Khalid bin Yazib bin Mu'awiyah bin Abu Sufian al Umawi, adalah seorang hakim Quraisy. Ia merupakan tokoh ilmuan sains terawal khusus dalam disiplin ilmu kimia dan perobatan. Bertanggungjawab menterjemah dan mengajar Arab dalam sains di samping menterjemah sains dan teknologi Mesir dan Yunani.

Khalifah Umayah dan Abbasiyah memberi perhatian dalam kegiatan penterjemahan buku Yunani ke bahasa Arab bagi pengembangan pembelajaran sains dan teknologi. Salah satu khalifah yang paling memainkan peranan penting dalam kegiatan penterjemahan buku Yunani ialah Abu Ja'far al Mansur.

Khalifah al Ma'mun membangunkan institusi seperti Bayt al Hikmah untuk pengkajian sains dan teknologi. Melalui institusi ini, telah banyak lahir ilmuwanilmuwan Muslim yang tersohor di dunia pada masa itu.

Berkembang pembelajaran sains dan teknologi di bandar-bandar utama yang dibangunkan umat Islam seperti Baghdad dan Cordova.

Terdapat pernyataan al Quran dan hadith mengenai aspek sains dan teknologi telah mendorong kajian dalam bentuk kesepaduan antara pernyataan wahyu dan penyelidikan 
praktikal di kalangan umat Islam.

Lahirnya tokoh penterjemah dan pengkajian sains seperti Hunain bin Ishak, al Kandi al Fazari, Ibn Musa, Ibn al Haitham, al Khawarizm dan lain sebagainya.

Lahirnya institusi bagi pembelajaran dan penyelidikan sains(Rahmi, 2019) dan teknologi seperti Balai Cerap, Maristan (Rumah Sakit besar), Dar al Hikmah, Bayt al Hikmah dan lain sebagainya.

Lahirnya beberapa teori sains, matematik dan selainnya yang diperkenal di peringkat awal oleh umat Islam.

Munculnya tokoh dan ilmuan sains dan teknologi mewakili umat Islam dalam berbagai disiplin sains seperti ahli kedokteran, ahli kimia, ilmuan matematik dan lain sebagainya.

Walaupun institusi sejarah pertumbuhan sistem persekolahan Islam lebih menitikberatkan pengajian agama, keadaan ini tidak bererti pembelajaran sains kurang diberi perhatian kerana ia dipelajari di institusi-institusi khas seperti Maristan dan Balai Cerap kerana sains lebih berbentuk praktikal.

Penguasaan Islam terhadap dunia sains dan teknologi pada masa itu sangat lama, bahkan belum sebanding dengan penguasaan sains dan teknologi yang sudah dicapai oleh Barat.

\section{Perkembangan Sains dan Teknologi dalam Islam}

Ketika banyak orang menulis atau berbicara tentang dunia muslim, mereka cenderung lebih membatasi nya dengan Negara-negara Arab daripada masyarakat Muslim lainnya. Mereka seringkali membuat pemisahan antara Turki, Persia, Spanyol, Byzantium, dan Arab yang mereka gambarkan secara terpisah, seakan-akan mereka adalah bangsa yang mewakili peradaban yang berbeda. Sedikit sekali orang yang menyadari bahwa peradaban islam tidak hanya berjalan di tempat. Sebaliknya, ia adalah peradaban ekpansif(Luqman, 2019) yang merangkul berbagai ras dan bangsa ke dalamnya melalui penaklukan dan propaganda serta berhasil memadukan mereka ke dalam satu tradisi Islam. Menimbang enyataan ini, ada beberapa kategori dunia Muslim sebagai semua komunitas yang menerimapesan-pesan Islam tanpa membedakan jenis ras nya. Dunia Muslim terdiri dari semua orang muslim yang terbentang dari Spanyol, hingga ke Asia Tengah dan seluruh Afrika Utara (termasuk Maghribi) hingga kepulauan Nusantara di Asia Tengah.

Tradisi ilmiah(Khairiyah, 2020) (sains) dalam masyarakat Muslim mempunyai nilai yang dikenal dengan "Islamis", yang dipengaruhi oleh kitab suci Al-Qur'an. Al-Qur'an melalui ayatayatnya senantiasa menyeru kepada orang-orang yang beriman untuk mengobservasi alam semesta dan merefleksikannya. Perintah untuk mencermati gejala ala mini, membekali pikiran Muslim untuk mengenali dan kemudian menerima semua ide-ide ilmiah yang sudah ada ketikakedatangan Islam.

Jadi walaupun anyak tradisi ilmiah Islam yang terbukti mengadobsi budaya luar. H.A.R. Gibb menguraikan "hukum" tersebut ke dalam tiga point, yaitu : Pertama, pengaruh-pengaruh budaya (bukan sekedar cangkokan superficial, tetapi elemen yang bear-benar terasimilasikan) selalu didahului dengan aktifitas yang sudah mapan dalam bidang yang berkaitan. Aktifitas yang sudah mapan inilah yang menciptakan faktor daya tarik yang tanpa itu asimilasi yang reatif tidak akan terwujud. Kedua, elemen pinjaman ini akan turut menyokong vitalitas kebudayaan peminjam sebagai yang utama. jika mereka berkembang dengan pesat sehingga menggeser atau mengancam menggantikan kekuatan spirit local, maka elemen itu bersifat destruktif, bukan konstruktif. Budaya yang hidup membolehkan elemen pijaman berkembang, sejauh elemen tersebut dapat beradaptasi dan bergabung dengan kekuatan local, tetapi dengan segala kekuatan, budaya yang hidup akan menentang elemen luar yang tumbuh berlebihan. Ketiga, budaya yang hidup mengabaikan atau menolak elemen dari budaya luar yang bertentangan dengan nilai fundamental, sikap emosional atau kriteria estetikanya. Akan ada usaha-usaha untuk meniru, tetapi peniruan tidak berarti "pengambilan" dank arena itu, budaya luar pasti akan mati. 
Inilah semangat dunia Muslim dalam mengambil ide ilmiah dan dalam waktu yang bersamaan membuang semua yang dipandang tidak sesuai dengan pandangan hidup Islam. Melalui ini, banyak tradisi ilmiah yang diadobsi dan disatukan. Yang paling signifikan di antara tradisi-tradisi yang diserap orang Muslim adalah tradisi Yunani.

Orang-orang Muslim lebih siap menyerap tradisi pengetahuan Yunani bersamaan dengan filafatnya. Astronomi adalah salah satu ilmu pengetahuan terkuno bagi orang-orang muslim. Padaawal tahu $750 \mathrm{M}$, khalifah Bani Abbasiyah, Harun alRasyid, telah mendirikan observatorium di Damaskus, di mana kajian astronomi dan berbagai eksperimen dilakukan. Banyak ahli astronomi muslim, seperti al-Farghani (850 M), al-battani (858-929 M), dan Thabit bin Qurra (826-01 M), berhasil membuat eksperimen, teori dan pandangan kosmologi Islam lebih maju. Al-Battani adalah ilmuan Muslim yang dikenal karena banyak penemuannya dalam teori asronomi ternyata lebih akurat daripada Ptolemy (pakar astronomy Yunani) yang saat ini sangat dominan. Al-Battani megontrol nilai dalam kemiringan ekliptik (bagian matahari yang tampak jelas di antara bintang dalam setahun) dan gerakan lambat siang dan malam, jauh lebih akurat daripada Ptolemy. Al-Battani jugamenemukan bahwa ketidak bundaran matahari senantiasa berubah. Kira-kira satu abad setelah dua penemuan alBattani tersebut, di Kairo, Ibnu Yunis (w. 1009 M) menggabungkan dokumen-dokumen penelitian yang dibuat 200 tahun sebelumnya dan menyiapkannya untuk tabel astronomi Hakimite.

Di tempat lain dalam dunia muslim, ahli astronomi lainnya membuat lebih-lebih banyak lagi eksperien tentangastronomi. Di spanyol, al-Zarkali (1029-1087 M) dari Kordoba merancang tabel astronomi Toledian pada tahun $1080 \mathrm{M}$, yang memodifikasi skema Ptolemik tentang cakrawala dengan menganjurkan perbedaan bundar pada atap "epicycle" planet mercury. E ksperimen lainnya dilakukan oleh Ibn Bajjah dari Saragossa (w. 1139 M), Abu Bakr dari Granada (w. 1200 M). kemajuan orang-orang muslim dalam bidang astronomi lebih signifikan dan ini adalah bukti dari banyaknya observatorium yang dikonstruksi oleh dunia muslim.

Di samping yang telah ada di Damaskus dan Baghdad, ada lagi observatorium terkenal, seperti di Raqqa yang dibangun oleh al-Battani, di Shiraz yang dibangun oleh Abd Rahman alsufi, di Hamadan, yaitu yang dipakai oleh Ibn Sina, dan di Maragha yang dibangun oleh Hulagu khan pada tahun 1261 M, dan digunakan oleh Nashruddin al-Thusi. Di samping itu ada juga di Samarkhand yang dibangun oleh Ulugh Beh di mana para Ilmuan seperti Qadizallah, Ali Qush dan Ghiyath al-Din al-Khashani menghasilkan banyak kajian astronomi dan eksperimen. Murad, seorang Sultan Usmaniyah juga membangun observatorium di Istanbul untuk pakar astronomi istana Taqiyuddin. Disamping para astronomer individu tadi, terdapat juga kelompok Ikhwan al-Shafa' (The Brothers of Purity) yang mengkompilasikan karya-karya ilmiahnya yang dikenal dengan Rasa'il Ikhwan al-shafa'. Dalam karya ini, mereka mengembangkan teori-teori astronomi dan kosmologi lainnya, seperti astrologi, meteorology, geologi, dan geografi. Kelompok ini, yang identitas ebenarnya masih controversial, hidup sekitar tahun 950-1030 M. Mereka adalah sekelompok ilmuan tersembunyi yang endiskusikan isu-isu sains dan filsafat.

Disiplin ilmu yang senantiasa berkaitan dengan astronomi adalah bidang matematika. Sudah menjadi fakta bahwa kebanyakan pakar astronomi di dunia muslim aalah pakar di bidang matematika. Sebagai contoh adalah al-Khawarizmi (w. 835 M), Ibn Abu 'Ubaida dari Valencia, Maslama al-Majriti dari al-Andalus (w. 1007 M), dan 'Umar al-Kayyam (1048-1132 M), mereka semua adalah ahli bidang matematika dan sealigus astronomi. konstribusi mereka dalam bidang matematika sebagai ilmu asti sungguh tidak tertandingi selama abad pertengahan. Contohnya adalah "Umar alKayyam, yang dikenal dengan karya "kalender Jalali” yang sangat sempurna dan dipakai di Persia sebagai penanggalan. Karya tersebut dipercaya lebih akurat dibanding kalender Gregorian (kalender yang diperkenalkan oleh Pope Gregory XIII pada tahun 1582).

Orang muslim juga menonjol dalam bidang sains lainnya, yaitu kimia. Dalam bidang ini, terdapat Khalid bin Yazid, cucu dari khalifah pertama Bani Umayyah. Ada juga Mu'awwiyah 
yang merupakan pakar kimia pertama dalam dunia muslim, kemudin diikuti oleh Ja'far Muhammad al-Shadiq (w. 765 M). Adapun pakar kimia terbesar dalam dunia Muslim adalah Jabir bin Hayyan (w. 776 M) yang memiliki karyakarya yang terdiridari 500 risalah yang kesemuanya hamper berisi tentang ilmu kimia dan empat puluh di antaranya masih bisa dijumpai hingga saat ini.

Mengomentari karya-karya Jabir di atas, C.I Figuirin mengatt mustahil jika menafikan peranan ilmu kimia dalam perkembangan fisikamodern saatakan bahwa "adalah hal yang sangat mustahil jika menafikan peranan ilmu kimia dalam perkembangan fisika modern saat in"i. para pakar kimia adalah orang pertama yang mempraktekkan metodeeksperimen. Lebih lanjut, dengan menyatukn angka logis dari sejumlah fakta dan penemuan dalam aksi molekul suatu benda, mereka telah mengusung kimiamodern lebih awal pada abad kedelapan Masehi. Geber (Jabir) telah mempraktekkan kaidah-kaidah aliran eksperimen, berisikan laporan tentang perkembangan dan operasi yang mengkonfirmasikan metode ini, dan ini dalam investigasi kimia.

Al- Razi adalah pakar kimia yang karyanya the Secret of Secrets, berisi keterangan yang sangat jelas tentang proses kimia dalam topik-topik seperti peleburan baja, sublimasi, pengolahan caustic soda, ammonia, sodium dan ammonium sulphide, pengolahan glycerin dari minyak zaitun, dan sebagainya. Al-ir aqi adalah juga contoh pakar kimia terkemuka lainnya. Tokoh-tokoh tersebut yang tidak diragukan lagi memiliki memiliki sejumlah karya yang sangat penting bagi kimia modern dan menjadi topic inti dalam sains.

Fisika juga merupakan cabang sains yang tumbuh subur di kalangan dunia Muslim semasa abad pertengahan yang melukiskan tradisi sains yang tinggi dalam umat Islam. Karya yang sangat penting dalam kajian ini dihasilkan oleh para ilmuan Muslim, seperti Qutb al-Run al-Sirazi, Ibn al-Haitan, (Alhazen), dan al-Biruni. Ibn alHaitun adalah murid terbesar Ptolemy dan Witelo dalam bidang optic. Ibn al-Haitam membuat penemuan yang penting dalam kajian gerakan, seperti prinsip inertria (kelembapan) dan mentransformasikan kajian optic ke dalam sains baru. Ibn al-Haitam melakukan eksperimen untuk menentukan gerakan yang berbentuk garis lurus pada cahaya (rectilinear motion of light), sifat bayangan, kegunaan lensa, kamera obsura yang semuanya dikaji secara matematis untuk pertamakalinya, serta masih banyak lagi kajian penting dalam fenomenaoptik. Dalam pembiasan, Ibn al-Haitam mengusulkan kecepatan empat persegi panjang pada permukaan pembiasa beberapa abad sebelum Isac Newton menemukan prinsip "least time".

Al-Birruni adalah pakar fisika yang terkenal dengan penentangannya terhadap aliran fisika Aristoteles, khususnya paa gerakan dari ruang (motion and space), yang ternyata diserang bukan hanya dengan rasio semata, tetapi juga dengan observasi. AlBirunni dipercaya memiliki peninggalan dalam tradisi fisika yang mendorong lahirnya kajian mekanik, hydrostatic, dan cabang-cabang sains yang berkaitan. Ilmuan muslim seperti Ibn Bajjah mengikuti jejak al-Biruni dan mengembangkan teori "Inklinasi” yang diikuti peletakan dasar teori daya dorong lainnya dan konsep momentum yang kemudian dijabarkan oleh para ilmuan barat setelah abad pertengahan.

Filsafat natural (natural philosophy) juga tumbuh subur di dunia Muslim. Di antara tokohtokohnya adalah Ibn Sina, al-Farabi, al-Kindi, al-Biruni, Ibn Rusyd, Ibn Bajja, al-Ghazali, dan tokoh-tokoh lainnya yang memberikan konstribusi yang besar kepada filsafat natural. Sebagian besar mereka sangat rajin mendukung filsafat natural Aristoteles, namun sebagian lainnya seperti al-ghazali, mengambil posisi yang bersebelahan dan terkadang sangat radikal dalam menyikapi aliran filsafat Aristoteles. Para pakar filsafat natural inilah yang bertanggungjawab dalam menterjemahkan filsafat yunani ke dalam bahasa Arab dan kemudian mengusungnya ke Barat. Sumbangan mereka terhadap tradisi ilmiah Islam tidak kurang penting daripada sumbangan para pakar fisika, kimia, matematika, astronomi, dan kedokteran. Merekamerupakan pakar yang benar-benar menguasai banyak disiplin ilmu. Ibn Sina dan al-Ghazali adalah filosof besar, sebagaimana juga dikenal sebagai ahli fisika tersohor. 
Karya mereka di bidang kedokteran tidak kalah pentingnya disbanding dengan karya mereka di bidang filsafat. Penemuan-penemuan ilmiah, eksperimen dan teori yang pernh dilakukan ilmuan Muslim bukanlah sempit. Sungguh tradisi mereka sangat komprehensif untuk mendukung lahirnya revolusi sains (ilmu pengetahuan). Jikailmuan Muslim tidak melakukan apa yang telah mereka kerjakan, dalam berbagai bidang sains, niscaya revolusi sains (ilmu pengetahuan) di Eropa Barat tidak akan pernah timbul pada saat itu. Walaupun kemudian revolusi sains semacam ini tidak muncul di kalangan kaum Muslimin.

Islam memang dilahirkan selain sebagai agama, juga sebagai sumber sains dan teknologi. Islam mengajak manausia untuk berfikir serta menganalisis alam semesta beserta fenomenanya (makrokosmos). Di dalama makrokosmos tersebut terkandung simpanan ilmu pengetahuan yang maha kaya, di samping ilmu pengetahuan yang tersimpan pada diri manusia sebagai mikrokosmos.

\section{Faktor Penghambat Perkembangan Sains dan Teknologi dalam Islam}

Banyak kalangan ilmuan, baik para kritikus maupun apologetic, dengan berbagai argument berusaha menjelaskan mengapa revolusi tidak terjadi di dunia Muslim?. Hal ini bukan bermaksud untuk mengangkat kembali argumentasi mereka, tetapi suatu penelitian diperlukan untuk membuat kritik atas argumentasi mereka, tetapi suatu penelitian diperlukan untuk membuat kritik atas argumentasi para kritikus yang menuduh bahwa tabiat Islam sebagai suatu agama adalah yang bertanggungjawab atas kegagalan ini. Pervez Amrali Hoodbhoy kiranya adalah orang yang paling memperolok-olok dengan kritikannya yang cenderung kepada tuduhan yang tidak terbantahkan. Dalam usahanya mengumpulkan argumentasi atas kegagalan revolusi sains terjadi di dunia Muslim, Hoodbhoy menyingung filsafat sebagai berikut:

"Masyarakat yang berorientasi pada doktrin fatalisme, atau seseorang yang terlalu diintervensi oleh Tuhan dan yang merupakan bagian dari matrik sebab akibat (kausalitas), terpaksa menghasilkan individu-individu yang kurang berhasrat menyelidiki hal-hal yang tidak diketahui dengan piranti sains".

Kemudian Hoodbhoy selalu menyindir bahwa tabiat hukum islam telah mengobarkan permusuhan selama berabad-abad terhadap elemen-elemen kapitalitas yang dianggap sebagai prasyarat perkebagan sais. Penjelasan semacam ini, yang sama sekali tidak berdasar dan merupakan distorsi fakta sejarah dan pandangan keliru terhadap Muslim dan filsafat Islam.

Di sisi lain, para apologetis menganggap bahwa al-Ghazali sebagai orang yang berperan dalam menggagalkan revolusi sains dalam dunia Muslim. Mereka berargumen bahwa karya al-Ghazali tentang teologi Asy'ari dan Tasawwuf memberikan pukulan telak terhadap pertumbuhan tradisi sains orang muslim. Pendapa tini bertolak belakang fakta bahwa bagahazali sendiri adalah ilmuan sains yang mempunyai sejumlah karya yang dengan tepat digambarkan oleh Seyyed Hossein Nasr bahwa "Risalah te"mahsyur al-Ghazali pada abad 5 $\mathrm{H} / 11 \mathrm{M}$ yang mengkritik filosof rasionalistik pada zamannya, menandai kemenangan akhir pemikiran intelek terhadap rasio logika yang independent sebuah kemenangan yang tidak menghancurkan filsafat rasionalistik sama sekali menjadikan nya berhubung dengan pengetahuan rohani/batin. Dengan hasil kekalahan dan penaklukan yang dilakukan oleh alGhazali dan tokoh-tokoh penganut silogis dan sistemis filsafat Aristoteles di abad 5 H/11 M, tradisi ilmu rohani Islam bisa bertahan hidup hingga saat ini dan tidak tercekik seperti lainnya dalam atmosfir yang terlalu rasionalistik.

Jikalau kritik dan apologi ditolak, maka di manakah keberadaan argument yang tepat untuk menjelaskan keadaan yang menyedihkan atas fenomena sains dalam dunia muslim, khususnya setelah abad $13 \mathrm{M}$. mengilas balik faktor eksternal dan internal mungkin dapat menunjukkan jawaban atas pertanyaan ini.

Secara eksternal, dua invasi yang berdampak permusuhan telah dilakukan terhadap dunia Muslim. Kedua invasi ini adalah invasi bangsa Mogolia dan kaum salib. Bangsa Mongolia 
dikenal sangat biadab, penghasut perang yang sangat primitive yang banyak menggarong kota dan menghancurkan berbagai peradaban yang telah lama kokoh, ulai dari Cina sampai Eropa Timur. Menurut David Nichole, gerombolan yang biadab ini kemudian menyerang Timur Tengah dan menguasainya selama setengah abad (1218-1268 M). Selama periode ini mereka tidak hanya meneror masyarakat, tetapi juga terlibat aktif dalam menghancurkan struktur-struktur penting yang merupakan hasil sains yang besar. David Nicolle menggambarkan bahwa:

"Budaya pengrusakan bangsa Mongolia sangat besar dan mencakup perusakan kota dan sekolahan, pembantaian guru dan ilmuwan serta melenyapkan para ilmuwan. Para ahli menduga bahwa baangkitnya peradaban Eropa Barat dari kondisi budaya dan teknologinya yang terbelakang, berganti menjadi bangsa adidaya, diantaranya disebabkan oleh perusakan yang menimpa dunia Muslim yang dilakukan oleh Mongolia, kemudian dilanjutkan penjarahan pasukan salib Konstantinopel Byzantium pada tahun 1204".

Sebagai sebuah pandangan mengenai kondisi perkembangan sains dan teknologi Barat, maka berikut ini kutipan pendapat Seyyed Muhammad Naquid al-Attas yang menganggap bahwa peradaban Barat(M. Dahlan M, 2018) yang telah melahirkan pandangan dunia Barat, bukanlahproduk satu aliran pemikiran, melainkan hasil dari banyak kecenderungan dan pengarauh yang banyak diantaranya tidak bias disesuaikan satu sama lainnya. Artinya alAttas menganggap bahwa Barat harus mampu mengakui semua peradaban sebelumnya yang dulu pernah menjadi sumber pengembaangan peradaban, termasuk di dalamnya peradaban Islam.

Pembahasan berisi ringkasan hasil penelitiannya, keterkaitan dengan konsep atau teori dan hasil penelitian lain yang relevan, interpretasi temuan, keterbatasan penelitian, serta implikasinya terhadap perkembangan konsep atau keilmuan.

\section{Simpulan}

Berdasarkan pembahasan di atas, dapat diambil beberapa kesimpulan sebagai berikut; Terdapat ilmuan Barat beranggapan kedudukan umat Islam dan ilmuan sainsnya hanya sekadar memindahkan dari pencapaian sains Yunani dan menafikan sejarah sains dan teknologi Islam yang pernah mengalami kejayaan panjang dengan segala prestasinya.

Anggapan negatif ini adalah tidak benar kerana aspek ilmu-ilmu berkaitan dengan kebendaan seperti aspek sains dan teknologi merupakan ilmu yang senantiasa berkembang dan saling memberikan sumbangan antara ilmu yang sebelumnya dengan yang sesudahnya. Hal ini berarti, sains dana teknologi Islam yang pernah mengalami kejayaan merupakan sumbangan terbesar dalam pengembangan sains dan teknologi

Barat.

Bagi pihak yang menafikan peranan umat Islam dalam sains atau peranannya sekadar memindahkan dari filsafat Yunani, berarti juga telah penafian hukum sains yang berbasis kepada pengembangan di samping penafian realitas kejayaan umat Islam dalam sejarah umat manusia.

Realitas sejarah membuktikan bahwa dari sisi kualitas, kemajuan sains daan teknologi umat Islam pernah melampaui kualitas sains dan teknologi pada saat ini, bisa dilihat dengan kualitas ilmuwan dan karya-karya yang dihasilkan. Adapun dari sisi kuantitas, kejayaan sains dan teknologi umat Islam sangat lama, sehingga kejayaan Barat dalam penguasaan sains dan teknologi belum sebanding dengan lamanya kejayaan sains dan teknologi Islam.

Kemajuan sains dan teknologi Barat modern merupakan hasil pemindahan dari kejayaan sains dan teknologi Islam di Baghdad, Spanyol dan Kepulauan Sicily.

Realitas ini secara historis harusnya mampu membangkitkan motivasi kepada umat Islam untuk bangkit dari ketertinggalan dalam bidang sains dan teknologi.

Saat ini, Barat sedang mengalami kejayaan di bidang sains dan teknologi, akan tetapi 
krisis kepercayaan juga melanda merekaa karena sekulerisme dan aatheisme yang mereka anut. Adapun Islam, saat ini sedang berupaya menguasai sains dan teknologi Barat, belum sampai pada persaingan dalam produksi sains dan teknologi. Kebangkitan sains dan teknologi dapat ditempuh jika ada upaya integrasi secaya nyata ilmu umum dengan agama.

\section{Daftar Pustaka}

AR, M. (2016). Sains, Teknologi, Dan Nilai-Nilai Moral. Elkawnie, 2(2), 109. https://doi.org/10.22373/ekw.v2i2.2657

Baharudin, M. (2016). EKSISTENSI TUHAN DALAM PANDANGAN ATEISME. Wahana Akademika: Jurnal Studi Islam Dan Sosial, 2(1), 95. https://doi.org/10.21580/wa.v2i1.824

Basyir, J. (2019). KEARIFAN LOKAL : Refleksi Diri Masyarakat To Lotang Sebagai Khalayak Media. Hikmah, 12(2), 208. https://doi.org/10.24952/hik.v12i2.857

Firman, F. (2018). Ilmu Pengetahuan, Teori Dan Penelitian. 1, 1-15. https://doi.org/10.31227/osf.io/8jtqr

Hadi, A. (2016). Metode Pengajaran Ilmu Tauhid. Al' Ulum, 56(2), 29-38. https://ojs.uniskabjm.ac.id/index.php/ULUM/article/view/411

Khairiyah, S. (2020). TRADISI ILMIAH ILMUWAN MUSLIM DI NUSANTARA. Islamijah: Journal of Islamic Social Sciences, 1(2), 113. https://doi.org/10.30821/islamijah.v1i2.7222

Luqman, S. (2019). Volume VIII Nomor 2 Maret - Agustus 2019. Dakwah Antar Budaya Di Era Cyber, VIII, 95-116.

M. Dahlan M. (2018). Kontribusi Peradaban Islam terhadap Peradaban Eropa. Rihlah, 06(01), 1-12.

Mardliyah, W., Sunardi, S., \& Agung, L. (2018). Peran Manusia Sebagai Khalifah Allah di Muka Bumi: Perspektif Ekologis dalam Ajaran Islam. JURNAL PENELITIAN, 12(2), 355. https://doi.org/10.21043/jp.v12i2.3523

Mukhlis, F. H. (2015). Model Penelitian Kalam ; Teologi Islam (Ilmu Kalam) Ahmad Hanafi. Dialogia: Jurnal Studi Islam Dan Sosial, 13(2), 137-148.

Mutia, M. (2018). TEKNOLOGI DALAM AL-QUR'AN. Jurnal Ilmiah Islam Futura, 6(2), 70. https://doi.org/10.22373/jiif.v6i2.3048

Nashir, H. (2002). Sekuralisme Politik dan Fundamentalisme Agama: Ketegangan Kreatif Hubunan Agama dan Politik. Unisia, 25(45), 154-163. https://doi.org/10.20885/unisia.vol25.iss45.art3

Nurdin, A., A. Samad, S. A., \& Samad, M. A. (2019). DASAR EPISTEMOLOGI DALAM FILSAFAT PENDIDIKAN ISLAM. Jurnal MUDARRISUNA: Media Kajian Pendidikan Agama Islam, 9(2), 454. https://doi.org/10.22373/jm.v9i2.5183

Prasanti, D. (2018). Model - Model Penelitian Tindakan Kelas. Jurnal Ilmu Komunikasi, 6(1), 13-21.

Qoqom, I. (2019). Hukum Kausalitas Al Ghazali Dalam Proses Konseling Islami. Transformatif, 3(1), 6884. https://doi.org/10.23971/tf.v3i1.1243

Rahmi, P. (2019). Pengenalan Sains Anak Melalui Permainan Berbasis Keterampilan Proses Sains Dasar. Jurnal Pendidikan, 5(2), 43-55.

Sari, M., \& Asmendri. (2018). Penelitian Kepustakaan (Library Research) dalam Penelitian Pendidikan IPA. Penelitian Kepustakaan (Library Research) Dalam Penelitian Pendidikan IPA, 2(1), 15. https://ejournal.uinib.ac.id/jurnal/index.php/naturalscience/article/view/1555/1159

Siregar, M. (2019). KRITIK TERHADAP TEORI DEKONSTRUKSI DERRIDA. Journal of Urban Sociology, 2(1), 65. https://doi.org/10.30742/jus.v2i1.611

Syarifuddin, S. (2018). PENDEKATAN HISTORIS DALAM PENGKAJIAN PENDIDIKAN ISLAM. KREATIF: Jurnal Studi Pemikiran Pendidikan Agama Islam, 13(2), 121-133. https://doi.org/10.52266/kreatif.v13i2.91 